J. Clin. Chem. Clin. Biochem.

Vol. 23, 1985, pp. 35-39

\title{
Laboratory and Clinical Experience with a Monoclonal Antibody-Based Radioimmunoassay for Serum Total Thyroxine
}

\author{
By T.J. Wilke, T.J. Sheedy and D. A. Hirning \\ Endocrine Department, Commonwealth Pathology Laboratory, Toowoomba, Queensland, Australia
}

(Received February 28/August 31, 1984)

Summary: The performance characteristics and diagnostic value of a monoclonal antibody-based radioimmunoassay for serum total thyroxine (Mallinckrodt) are described. Between-batch precision (coefficient of variation) was $10.4 \%$ at $87 \mathrm{nmol} / 1$ and $3.3 \%$ at $185 \mathrm{nmol} / 1$. Scatchard analysis revealed a linear plot with a $\mathrm{K}_{\mathrm{a}}$ of $5.4 \times 10^{8} \mathrm{l} / \mathrm{mol}$.

Sensitivity was $4.5 \mathrm{nmol} / 1$ of thyroxine. An association study showed that the assay reached equilibrium well within the specified incubation time. Cross-reaction of triiodothyronine and reverse triiodothyronine in the assay was $0.6 \%$ and $25.0 \%$ respectively. Analytical recovery was $91-110 \%$. Linearity was well demonstrated but dilutions of a high concentration of thyroxine in serum did not parallel the standard curve. The correlation coefficient for comparison with a polyclonal antibody assay was 0.95 for 83 patients. The diagnostic accuracy of the monoclonal antibody assay was adequate for most patients with thyroid disease, pregnant women, oral contraceptive users and subjects on thyroxine-replacement therapy. Measurement of total thyroxine by a monoclonal antibody-based method shows no definite advantage over the conventional polyclonal antibody assay.

Erfahrungen in Laboratorium und Klinik mit einem Radioimmunassay für das gesamte Thyroxin im Serum auf der Grundlage eines monoklonalen Antikörpers

Zusammenfassung: Die Charakteristika der Durchführung und der diagnostische Wert eines Radioimmunassay mit monoklonalem Antikörper für das gesamte Thyroxin im Serum (Mallinckrodt) werden beschrieben. Die Impräzision von Serie zu Serie beträgt als Variationskoeffizient 10,4\% bei $87 \mathrm{nmol} / \mathrm{l}$ und 3,3\% bei 185 $\mathrm{nmol} / \mathrm{l}$. Die Scatchard-Analyse ergab einen linearen Verlauf mit einem Wert für $\mathrm{K}_{\mathrm{a}}$ von $5,4 \times 10^{8} \mathrm{l} / \mathrm{mol}$.

Die Empfindlichkeit betrug 4,5 nmol/1 Thyroxin. Eine Bindungsstudie ergab, daß das Gleichgewicht innerhalb der angegebenen Inkubationszeit völlig erreicht wird. Die Kreuzreaktionen von Triiodthyronin und reverse Triiodthyronin betrugen 0,6 bzw. $25,0 \%$. Die analytische Wiederfindung betrug $91-110 \%$. Es konnte völlige Linearität nachgewiesen werden, jedoch ergaben Verdünnungen einer hohen Konzentration von Thyroxin im Serum keinen parallelen -Verlauf mit der Standardkurve. Der Korrelationskoeffizient für ein Vergleichsverfahren mit polyklonalem Antikörper betrug $r=0,95(n=83$ Patienten). Die diagnostische Richtigkeit des Radioimmunassay mit monoklonalem Antikörper war für die meisten Patienten mit Schilddrüsenerkrankungen, für Frauen, die orale Kontraceptiva einnahmen oder schwanger waren, sowie Personen unter Thyroxin-Substitution genügend. Die Bestimmung des Gesamtthyroxins unter Verwendung eines monoklonalen Antikörpers zeigt keinen deutlichen Vorteil gegenüber der Verwendung konventioneller polyklonaler Antikörper. 


\section{Introduction}

Monoclonal antibodies, produced by classical hybridoma techniques $(1,2)$ offer several advantages for the purposes of radioimmunoassay (RIA), namely monospecificity and elimination of the bleed-tobleed variation which is associated with animal antisera $(3,4)$. Commercial assay kits, using monoclonal antibody technology, have achieved relatively wide use in the estimation of hormones such as thyrotropin and chorionic gonadotropin because assays employing classical polyclonal antisera to these hormones display predictable cross-reaction with structurally-related molecules (5). However the role of monoclonal antibody technology in the assay of a hormone such as total thyroxine $\left(\mathrm{T}_{4}\right)$ is uncertain as there are already a large number of excellent commercial kits, utilizing polyclonal antisera, available for this purpose $(6,7)$.

The aim of this present study was to examine the value of using a monoclonal antibody system for the estimation of $\mathrm{T}_{4}$ by comparing the laboratory and clinical performance of the new monoclonal antibody sectionally processed coated tube (SPAC) total $\mathrm{T}_{4}$ kit from Mallinckrodt with that of a well established conventional $\mathrm{T}_{4}$ assay (Amerlex: Amersham International) $(8,9)$.

\section{Materials and Methods}

All sera were assayed for total $T_{4}$, triiodothyronine $\left(T_{3}\right)$ uptake ratio, free $\mathrm{T}_{4}\left(\mathrm{FT}_{4}\right)$ and $\mathrm{T}_{3}$, and the free thyroxine index (FTI); computed by multiplying the $T_{4}$ concentration by the $T_{3}$ uptake ratio. Reference intervals, for all of these parameters, were determined in our laboratory.

$\mathrm{T}_{4}$ was determined by the Amerlex (Amersham International Ltd., Amersham, Bucks, U.K.) and the MCA (SPAC) T 4 (Immunoassay Systems, Mallinckrodt, Inc. St. Louis, MO 63134) RIA kits. $\mathrm{FT}_{4}$ and $\mathrm{T}_{3}$ were measured with Amerlex RIA kits (Amersham International) and $T_{3}$ uptake was estimated with the MAA kit (Amersham International).

Within-batch precision of the $T_{4}$ kits was evaluated by assaying three different concentrations of a lyophilized control material 20 times in a single batch (Ortho tri-level ligand assay control, lot no. LIGX01; Ortho Diagnostics Systems, Inc., Raritan, NJ 08869). Between-batch precision was assessed by testing three concentrations of ligand once per day for seven days.

Sensitivity is defined in this study as the 'minimal detection limit' of an assay (10). It was characterised, for each $\mathrm{T}_{4}$ assay, by using 20 replicates of a zero calibrator to calculate the concentration which corresponds to the value for counts per minute that is two standard deviations from the mean.

An association study was performed, with low, normal and high $\mathrm{T}_{4}$ concentration sera, to determine the time needed for the reactants to reach equilibrium.

The specificity of the antibody in each $\mathrm{T}_{4}$ kit was studied by comparing the molar ratio (expressed as a percentage) between the quantity of $T_{4}$ and the quantity of the structurally related thyroid hormones $\left(T_{3}\right.$ and reverse $\left.T_{3}\left(\mathrm{rT}_{3}\right)\right)$ which cause $50 \%$ displacement of the $T_{4}$ tracer. $T_{4}$ and $T_{3}$ were obtained from the Sigma Chemical Company and $\mathrm{rT}_{3}$ from Henning Berlin.
Recovery was studied by assaying aliquots of the same hypothyroid sample to which were added known and increasing amounts of $T_{4}$ standard. Recoveries were then calculated, as percentages, from the quotient of observed and calculated $T_{4}$ concentration. Parallelism and linearity were determined by assaying dilutions of a high concentration of $\mathrm{T}_{4}$ in serum with a buffer solution containing, per litre, $1 \mathrm{~g}$ of bovine serum albumin, $150 \mathrm{mmol}$ of $\mathrm{NaCl}$, and $67 \mathrm{mmol}$ of phosphate buffer, $\mathrm{pH} 7.35$.

\section{Patients}

Thyroid status was determined using assays of serum $\mathrm{FT}_{4}$, followed by assays of serum $\mathrm{T}_{3}$ or thyrotropin (TSH) where appropriate. Subjects were then classified according to biochemical and clinical findings as follows:

Euthyroid controls: Fifty three healthy hospital and laboratory staff (20 men, 33 women).

Patients with thyroid disease: Fifteen hyperthyroid patients (4 men, 11 women) were all clinically hyperthyroid and had $\mathrm{FT}_{4}$ concentrations $>20 \mathrm{pmol} / /$ and $T_{3}$ concentrations $>2.5 \mathrm{nmol} / /$. Fifteen hypothyroid patients ( 2 men, 13 women) were all clinically hypothyroid and had $\mathrm{FT}_{4}$ concentrations $<10$ pmol/l and thyrotropin levels $>6 \mathrm{mU} / \mathrm{h}, \mathrm{T}_{3}$ values were within normal limits in nine hypothyroid patients.

Euthyroid subjects with increases in thyroxine-binding globulin (TBG) binding capacity: Third trimester pregnancy: 20 women (gestational age range 30-39 weeks). Contraceptive pill users: 20 women.

Patients on thyroxine-replacement therapy: 20 patients ( 2 men, 18 women). All patients were clinically controlled on thyroxine and had normal $\mathrm{FT}_{4}$ concentrations.

\section{Statistical analysis}

The F-test was used for comparison of precision between the two methods analysed, Student's paired t-test for comparison of values between both $\mathrm{T}_{4}$ kits, and Pearson's correlation coefficient ( $\mathrm{r}$ ) to show the degree of linear association among the different variables. Further statistical analyses included Student's t-statistics for tests on regression coefficients (11) and the unpaired t-test for comparing means of different determinations with normal control mean values, for the various groups under study. A $p$ value of $\leqslant 0.05$ was considered significant.

\section{Results and Discussion}

\section{Laboratory evaluation}

\section{Precision}

The within-batch and between-batch precision for Amerlex and MCA (SPAC) $\mathrm{T}_{4}$ kits is shown in table 1. The performance of the Amerlex kit at three different concentrations was judged to be acceptable according to the criteria of Tonks (12), i.e. twice the coefficient of variation (CV) should be $<20 \%$, whereas the between-batch precision for the MCA (SPAC) $\mathrm{T}_{4}$ kit was $>10 \%$ at low and normal concentrations of $\mathrm{T}_{4}$. These variations were higher than those reported in several studies $(8,13)$ but similar to others $(6,7)$. However over the range of concentrations studies, there was no statistical difference in precision between the two methods (F-test). The ob- 
served difference in precision between methods most likely arises from the inherent problems of coatedtube technology $(10,14)$ rather than from the nature of the reagents such as antibody type.

Tab. 1. Within-batch and between-batch precision of $T_{4}$ kits as determined with low-, medium-, and high-concentration control sera.

\begin{tabular}{|c|c|c|c|c|c|c|}
\hline & \multicolumn{3}{|c|}{ Within-batch values } & \multicolumn{3}{|c|}{ Between-batch values } \\
\hline & Low & $\begin{array}{l}\text { Me- } \\
\text { dium }\end{array}$ & High & Low & $\begin{array}{l}\text { Me- } \\
\text { dium }\end{array}$ & High \\
\hline \multicolumn{7}{|l|}{ Amerlex } \\
\hline $\begin{array}{l}\text { Mean (nmol/l) } \\
\text { SD (nmol/l) } \\
\text { CV }(\%)\end{array}$ & $\begin{array}{r}30.5 \\
1.4 \\
4.7\end{array}$ & $\begin{array}{r}89.5 \\
2.4 \\
2.7\end{array}$ & $\begin{array}{c}193.9 \\
4.2 \\
2.2\end{array}$ & $\begin{array}{r}27.8 \\
1.4 \\
5.0\end{array}$ & $\begin{array}{r}93.8 \\
4.6 \\
4.9\end{array}$ & $\begin{array}{r}201.1 \\
6.2 \\
3.1\end{array}$ \\
\hline \multicolumn{7}{|l|}{ MCA (SPAC) } \\
\hline $\begin{array}{l}\text { Mean }(\mathrm{nmol} / \mathrm{l}) \\
\mathrm{SD}(\mathrm{nmol} / \mathrm{l}) \\
\mathrm{CV}(\%)\end{array}$ & $\begin{array}{r}29.9 \\
3.6 \\
11.9\end{array}$ & $\begin{array}{r}85.0 \\
6.6 \\
7.7\end{array}$ & $\begin{array}{r}191.0 \\
10.5 \\
5.5\end{array}$ & $\begin{array}{r}21.5 \\
2.7 \\
12.8\end{array}$ & $\begin{array}{r}87.1 \\
9.1 \\
10.4\end{array}$ & $\begin{array}{r}185.2 \\
6.1 \\
3.3\end{array}$ \\
\hline
\end{tabular}

Scatchard analysis (15), performed on data contained in the standard curve, revealed a curvilinear plot with the Amerlex antibody, indicating multiple antigenic binding sites. The calculated average affinity constant $\left(\mathrm{K}_{\mathrm{a}}\right)$ was $6.7 \times 10^{8} \mathrm{l} / \mathrm{mol}$. By comparison the monoclonal antibody produced a linear Scatchard plot, indicating a single binding site. The calculated $\mathrm{K}_{\mathrm{a}}$ of $5.4 \times 10^{8} \mathrm{l} / \mathrm{mol}$ was comparable with a previous report for this antibody (4). The $K_{a}$ values for both antibodies were similar to those reported in other RIA $T_{4}$ kits $(6,7)$. Although the calculated $\mathrm{K}_{\mathrm{a}}$ value for the Amerlex antibody was slightly higher than that of the monoclonal antibody, both were of sufficiently high affinity to provide assays with sensitivities greater than necessary for determination of serum $\mathrm{T}_{4}$ (minimal detectable dose for Amerlex $\mathrm{T}_{4}$ and MCA (SPAC) $\overline{\mathrm{T}}_{4}$ were $1.5 \mathrm{nmol} / 1$ and 4.5 nmol/1 respectively).

Association studies showed that the MCA (SPAC) $\mathrm{T}_{4}$ method reached virtual equilibrium in the specified incubation time (one hour) at the three different $T_{4}$ concentrations studied, whereas Amerlex achieved equilibrium before 45 minutes (stated incubation time), only at a high $T_{4}$ concentration. Amerlex reactions proceeded for two hours without reaching equilibrium at normal and low $\mathrm{T}_{4}$ concentrations.

\section{Intermethod comparison}

Using 83 serum samples, there was a high correlation $(r=0.95 \mathrm{p}<0.001)$ between $\mathrm{T}_{4}$ levels measured in the monoclonal antibody assay and those measured in the conventional antiserum RIA. This suggests that the monoclonal antibody is directed towards the same antigenic sites on $\mathrm{T}_{4}$ as the polyclonal antiserum. The relationship found was MCA (SPAC) $\mathrm{T}_{4}=0.875 \mathrm{x}\left(\right.$ Amerlex $\left.\mathrm{T}_{4}\right)+17.218$. The slope of the regression line was significantly different from unity $(p<0.001)$ and the intercept statistically different from zero $(p<0.001)$, indicating that the MCA (SPAC) $\mathrm{T}_{4}$ assay produces higher values than those of Amerlex $T_{4}$ throughout most of the assay range. In contrast, $T_{4}$ levels in low-, medium- and high-concentration control sera were lower when measured by the MCA (SPAC) $\mathrm{T}_{4}$ assay than by Amerlex $\mathrm{T}_{4}$ (tab. 1).

There was very little cross-reaction of $\mathrm{T}_{3}$ and $\mathrm{rT}_{3}$ in the Amerlex $\mathrm{T}_{4}$ assay ( $2.7 \%$ and $1.1 \%$ respectively) and $\mathrm{T}_{3}$ with $\mathrm{T}_{4}$ in the MCA (SPAC) assay $(0.6 \%)$. However cross-reaction of $\mathrm{rT}_{3}$ in the monoclonal $\mathrm{T}_{4}$ assay was high $(25.0 \%)$. Since, in normal subjects, $\mathrm{rT}_{3}$ circulated at a concentration $<1 \%$ than that of $\mathrm{T}_{4}(16)$, this cross-reaction would be unimportant in practice.

\section{Recoveries}

The Amerlex $\mathrm{T}_{4}$ method gave a mean recovery of 98\% (range 95-102\%) while the MCA (SPAC) method averaged a recovery of $100 \%$ (range $91-$ $110 \%$ ). As no single recovery was less than $85 \%$ or greater than $115 \%$, the recoveries found for both methods were acceptable according to the criterion of Logan (17).

The regression lines calculated for the correlation of added amount vs expected amount indicated that there were excellent linear recoveries in the monoclonal antibody and conventional antiserum RIA's ( $r$ $=1.00$ for both assays). In addition their slopes were not significantly different from unity nor intercepts statistically different from zero (slopes and intercepts for Amerlex and MCA (SPAC) T 4 , respectively, were $1.06-2.43$ and $1.05,-2.25)$. These results indicate that there is quantitative recovery in both assays independent of the concentration of $T_{4}$ to be measured.

\section{Test of parallelism}

Amerlex and MCA (SPAC) $\mathrm{T}_{4}$ methods produced good linearity on dilution throughout the assay range ( $r=1.00$ for both assays). The slope of the line for experimental values vs expected values was not significantly different from unity for the Amerlex assay (slope $=1.00)$. In contrast the MCA (SPAC) $\mathrm{T}_{4}$ assay failed to show parallelism (slope $=0.81, \mathrm{p}<$ 
0.01). The non-parallelism, indicating interference in the monoclonal antibody assay by factors other than those which can be clearly identified by their physiochemical similarity to $\mathrm{T}_{4}(10)$, could explain the higher MCA (SPAC) $T_{4}$ values in patient's serum compared with those determined by the Amerlex method.

\section{Clinical evaluation}

Table 2 shows means for $\mathrm{FT}_{4}$ and results for the MCA (SPAC) and Amerlex $\mathrm{T}_{4}$ kits in six clinical groups. The percentage of patients in these groups whose values lie outside reference intervals for $\mathrm{FT}_{4}$ and the two $\mathrm{T}_{4}$ kits is also shown.

Tab. 2. Serum $T_{4}$ and $\mathrm{FT}_{4}$ values in six clinical groups.

\begin{tabular}{|c|c|c|c|}
\hline \multirow[t]{2}{*}{ Group } & \multirow[t]{2}{*}{$\begin{array}{l}\mathrm{FT}_{4} \\
(\mathrm{pmol} / \mathrm{l})\end{array}$} & \multicolumn{2}{|c|}{$\begin{array}{c}\mathrm{T}_{4} \\
(\mathrm{nmol} / \mathrm{l})\end{array}$} \\
\hline & & Amerlex & $\begin{array}{l}\text { MCA } \\
\text { (SPAC) }\end{array}$ \\
\hline \multicolumn{4}{|c|}{$\begin{array}{l}\text { Euthyroid (control) } \\
n=53\end{array}$} \\
\hline $\begin{array}{l}\text { Mean } \\
\text { SD }\end{array}$ & $\begin{array}{r}14.6 \\
2.2\end{array}$ & $\begin{array}{c}108.3 \\
19.6\end{array}$ & $\begin{array}{r}115.2 \\
24.7\end{array}$ \\
\hline \multicolumn{4}{|c|}{$\begin{array}{l}\text { Hyperthyroid } \\
n=15\end{array}$} \\
\hline $\begin{array}{l}\text { Mean } \\
\text { SD }\end{array}$ & $\begin{array}{l}47.2^{c}(100) \\
30.3\end{array}$ & $\begin{array}{l}193.2^{c}(93) \\
39.6\end{array}$ & $\begin{array}{l}181.9^{c}(73) \\
29.5\end{array}$ \\
\hline \multicolumn{4}{|c|}{$\begin{array}{l}\text { Hypothyroid } \\
n=15\end{array}$} \\
\hline $\begin{array}{l}\text { Mean } \\
\text { SD }\end{array}$ & $\begin{array}{l}6.5^{c}(100) \\
2.3\end{array}$ & $\begin{array}{l}47.7^{c}(93) \\
17.3\end{array}$ & $\begin{array}{l}51.9^{c}(73) \\
18.6\end{array}$ \\
\hline \multicolumn{4}{|c|}{$\begin{array}{l}\text { 3rd trimester pregnancy } \\
\mathrm{n}=20\end{array}$} \\
\hline $\begin{array}{l}\text { Mean } \\
\text { SD }\end{array}$ & $\begin{array}{l}9.1^{\mathrm{c}}(70) \\
1.5^{5}\end{array}$ & $\begin{array}{l}153.0^{c}(55) \\
25.3\end{array}$ & $\begin{array}{c}162.9^{c}(35) \\
23.5\end{array}$ \\
\hline \multicolumn{4}{|c|}{$\begin{array}{l}\text { On oral contraceptives } \\
n=20\end{array}$} \\
\hline $\begin{array}{l}\text { Mean } \\
\text { SD }\end{array}$ & $\begin{array}{l}13.0^{b}(0) \\
2.0\end{array}$ & $\begin{array}{l}139.3^{c}(30) \\
19.5\end{array}$ & $\begin{array}{l}144.2^{\mathrm{c}}(25) \\
21.6\end{array}$ \\
\hline \multicolumn{4}{|c|}{$\begin{array}{l}\text { On thyroxine } \\
\text { replacement therapy } \\
n=20\end{array}$} \\
\hline $\begin{array}{l}\text { Mean } \\
S D\end{array}$ & $\begin{array}{r}16.1(0) \\
3.4\end{array}$ & $\begin{array}{c}110.7(0) \\
18.3\end{array}$ & $\begin{array}{c}115.2(0) \\
23.6\end{array}$ \\
\hline
\end{tabular}

Statistical significance of difference from euthyroid (control) mean indicated by ${ }^{a} \mathrm{p}<0.05 ;{ }^{b} \mathrm{p}<0.01 ; \mathrm{c} p<0.001$. Numbers in parentheses are the percentages of patients whose values lie outside the reference interval by each measure.

\section{Patients with thyroid disease}

The mean values for $T_{4}$ by both methods - as expected - were increased $(\mathrm{p}<0.001)$ in hyperthyroidism. In this group one patient $(7 \%)$ had a normal $\mathrm{T}_{4}$ when measured by Amerlex whereas $T_{4}$ values assayed by the MCA (SPAC) kit were within the euthyroid range in four patients $(27 \%)$. Amerlex and MCA (SPAC) $\mathrm{T}_{4}$ values were significantly decreased $(p<0.001)$ in hypothyroid patients. These patients were distinguished with $93 \%$ accuracy from normal subjects by the Amerlex $\mathrm{T}_{4}$ kit (tab. 2) whereas only $73 \%$ of hypothyroid patients had MCA (SPAC) $\mathrm{T}_{4}$ values below normal limits.

Thus $T_{4}$ values measured by the conventional antibody RIA were a slightly more sensitive indicator of thyroid disease than those assayed by the monoclonal antibody assay.

Subjects with increased thyroid hormone binding capacity

The concentration of TBG progressively increases with the duration of pregnancy $(18,19)$. Therefore - as expected $-T_{4}$ values by both methods were significantly increased $(p<0.001)$ as compared with the control group in third trimester pregnants. In these women, more than one-half $(55 \%)$ of their $\mathrm{T}_{4}$ values by Amerlex were in the hyperthyroid range whilst about a third (35\%) of $T_{4}$ values assayed by MCA (SPAC) were elevated.

In oral contraceptive users, $\mathrm{T}_{4}$ values by both methods were increased ( $p<0.001)$, as a direct consequence of elevated TBG concentrations. Amerlex and MCA (SPAC) $\mathrm{T}_{4}$ values were elevated in $30 \%$ and $25 \%$ of patients on oral contraceptives, respectively.

Therefore, in sera of pregnant women and oral contraceptive users, the $T_{4}$ value was a more appropriate reflection of TBG concentration, when measured by the conventional RIA than by the monoclonal antibody assay. All 20 patients controlled on thyroxinereplacement therapy gave normal $\mathrm{T}_{4}$ values by Amerlex and MCA (SPAC) methods. Hence concentrations measured by the monoclonal antibody assay and by the conventional antibody RIA appeared to be of equivalent value in monitoring thyroxine-treated patients.

\section{Correlation between FTI and $\hat{F} T_{4}$}

There were good correlations between $\mathrm{FT}_{4}$ concentration and FTI values derived from each of the $T_{4}$ methods in euthyroid control subbjects and patients 
with thyroid disease (Amerlex, $\mathrm{r}=0.81 ; \mathrm{p}<0.001$ and MCA (SPAC), $\mathrm{r}=0.78 ; \mathrm{p}<0.001$ ). Thus FTI values derived from either the conventional or the monoclonal antibody $\mathrm{T}_{4}$ assay, were equally good in reflecting a patient's true thyroid status.

\section{Conclusions}

In conclusion, the monoclonal antibody used in the Mallinckrodt (SPAC) $\mathrm{T}_{4}$ had a similar affinity constant to that of a polyclonal antiserum and showed a clinically insignificant but high cross-reaction with the structurally-related thyroid hormone, $\mathrm{rT}_{3}$. In addition, the assay showed good sensitivity, quantitative recoveries and technical simplicity. Furthermore it demonstrated acceptable diagnostic accuracy, des- pite the slightly lower sensitivity of the assay as an index of thyroid status in thyroid disease, compared with that of a polyclonal antibody RIA. Therefore, in conclusion, a monoclonal antibody $\mathrm{T}_{4}$ assay is suitable for use in the clinical laboratory, but it offers no significant advantages over a RIA employing a conventional polyclonal antiserum.

\section{Acknowledgements}

The authors acknowledge Kay Waite, Howard Smith and Cres Eastman of the Endocrine Unit, Westmead Centre, New South Wales, Australia, for kindly performing the cross-reaction studies. The authors would also like to thank Frank Watson and Howard Smith for expert help with the Scalchard analysis and Doris Bardi$n i$ for her enthusiasm in collecting many of the euthyroid control samples for this study.

\section{References}

1. Köhler, G. \& Milstein, C. (1975) Nature 256, 495-497.

2. Köhler, G. \& Milstein, C. (1976) Eur. J. Immunol. 6, 511519.

3. Sevier, E. D., David, G. S., Martinis, J., Desmond, W. J., Bartholomew, R. M. \& Wang, R. (1981) Clin. Chem. 27, 1797-1806.

4. Ajit-Simth, K. A. \& Petersen, J. R. (1982) Clin. Chem. 28, 1654. Abstract.

5. Ridgway, E. C., Ardisson, L. J., Meskell, M. J. \& MudgettHunter, M. (1982) J. Clin. Endocrinol. Metab. 55, 44-48.

6. Hopkins, J. A. H., Edwards, L., Herner, A. E. \& Van Dreal, P. (1977) Clin. Chem. 23, 430-435.

7. Broughton, A., Hopkins, J. A. H., Edwards, L., Besch, N., Boone, J., Stougas, D., Langan, J. \& Wein, G. (1978) Clin. Chem. 24, 1257-1261.

8. Wilke, T. J. \& Turnbull, P. A. (1982) Ann. Clin. Biochem. 19, 104-107.

9. Wilke, T. J. (1983) Clin. Chem. 29, 74-79.

10. Chard, T. (1978) An introduction to radioimmunoassay and related techniques. North-Holland Publishing Company, Amsterdam.

11. Freund, J. E. (1979) Modern Elementary Statistics. PrenticeHall, Englewood Cliffs, NJ, pp. 384-388.

12. Tonks, D. B. (1963) Clin. Chem. 9, 217-233.

13. Beckala, H. R., Leavelle, D. E. \& Homburger, H. A. (1977) Clin. Chem. 23, 2177-2179.

14. Walker, W. H. C. (1977) Clin. Chem. 23, 384-402.

15. Scatchard, G. (1949) Ann. N.Y. Acad. Sci. 51, 660-672.

16. Corcoran, J. M. \& Eastman, C. J. (1978) In Current Thyroid Problems in Southeast Asia and Oceania. Hetzel B. S., Wellby, M. L. \& Höschl, R., Eds., Singapore, pp. 109-112.

17. Logan, J. E. (1972) CRC Critical Reviews in Clinical Laboratory Sciences 3, 271-289.

18. Wilke, T. J. (1982) Clin. Chem. 28, 2051-2056.

19. Wilke, T. J. (1983) Ann. Clin. Biochem. 19, 60-61.

Timothy J. Wilke

Endocrine Department

Commonwealth Pathology Laboratory

PO Box 36/614

Toowoomba

Queensland, 4350

Australia 
,

。 